\title{
EFEKTIVITAS PELATIHAN BERPIKIR POSITIF UNTUK MENURUNKAN KECEMASAN MENGERJAKAN SKRIPSI PADA MAHASISWA
}

\section{EFFECTIVENESS OF POSITIVE THINKING TRAINING TO REDUCE ANXIETIES DOING THESIS ON UNIVERSITY STUDENTS}

\author{
Atina Machmudati \\ R. Rachmy Diana \\ Program Studi Psikologi Universitas Islam Negeri Sunan Kalijaga Yogyakarta \\ Email: rachmy.diana@yahoo.com
}

\begin{abstract}
This research aims to know the effectiveness of positive thinking training in reducing the anxieties of students who are working on the thesis. The subjects in this research consisted of 24 students which 12 students into experimental group and 12 students into the control group. The subjects characteristics of the research is : 1) students of UIN Sunan Kalijga especially students of Social anda Humanities Faculty and Science and Technology Faculty 2) doing thesis, 3) having medium up to highest anxiety score in doing thesis, 4) ready to be subject of the research. This research uses two deferent groups (experimental and control groups) by pre-test and post-test design. The measurenment tool which is use in the research is the anxiety doing the thesis scale. The test using statistical analysis techniques Mann Whitney $U$ indicates that gain score between control and experimental group results value $p=0,002(p<0,005)$ so it can be concluded that there is a difference score of anxiety that significant between experimental and control group. Whereas the analysis results of wilcoxon signed rank indicates that post-test and pre-test experimental group gets value $p=0,002$ $(p<0,005)$, so it can be concluded that there is different of anxiety level on experimental group before and after treatment. The anxiety of students after getting positive thinking treatment indicates lower than before.
\end{abstract}

Keywords: Positive thinking training, anxiety, students.

\begin{abstract}
ABSTRAK
Penelitian ini bertujuan untuk mengetahui keefektifan pelatihan berpikir positif dalam menurunkan kecemasan mengerjakan skripsi pada mahasiswa. Subjek penelitian sebanyak 24 mahasiswa. Karakteristik subjek penelitian di antaranya adalah: 1) Mahasiswa Universitas X, khususnya mahasiswa Fakultas Isoshum dan Saintek, 2) Sedang mengerjakan skripsi , 3) Memiliki skor kecemasan mengerjakan skripsi yang sedang sampai sangat tinggi di antara populasi, dan 4) Bersedia menjadi subjek penelitian. Penelitian ini menggunakan dua kelompok group yang berbeda (kelompok kontrol ada 12 subjek dan kelompok eksperimen ada 12 subjek) dengan desain prates dan pascates. Alat ukur yang digunakan dalam penelitian ini adalah skala kecemasan menghadapi skripsi. Hasil uji statistika dengan menggunakan teknik analisis Mann Whitney $U$ menunjukkan bahwa gain score antara kelompok kontrol dan eksperimen menghasilkan nilai $\mathrm{p}=0.002(\mathrm{P}<0.05)$ sehingga dapat disimpulkan bahwa ada perbedaan skor kecemasan yang signifikan antara kelompok eksperimen dan kelompok kontrol. Sedangkan hasil analisis Wilcoxon Signed Rank menunjukkan bahwa skor pascates dan prates kelompok eksperimen mendapatkan nilai $p=0.002(P<0.05)$, sehingga dapat disimpulkan bahwa ada perbedaan tingkat kecemasan pada kelompok eksperimen sebelum dan setelah diberi perlakuan. Kecemasan mahasiswa setelah mengikuti pelatihan berpikir positif lebih rendah daripada kecemasan sebelum mengikuti pelatihan.
\end{abstract}

Kata kunci: Kecemasan, mahasiswa, pelatihan berpikir positif 
Salah satu persyaratan yang harus ditempuh seorang mahasiswa untuk meraih gelar sarjana strata 1 (S1) adalah melakukan penelitian ilmiah yang dilaporkan secara tertulis dikenal dengan sebutan skripsi. Mahasiswa dapat menyusun skripsi jika sudah memenuhi syarat-syarat pengambilan skripsi yang sudah ditentukan oleh tiap fakultas. Sebagai tahap akhir dalam proses kegiatan akademik di bangku kuliah untuk meraih gelar sarjana, setiap mahasiswa tentunya mengerahkan seluruh tenaga dan fikiran yang dimiliki sejak awal penyusunan skripsi. Hal tersebut dilakukan guna mendapatkan hasil penelitian yang baik dan dapat menyelesaikannya pada target yang telah ditentukan.

Permasalahannya, sebagaimana diungkapkan Abidin (2006), bagi sebagian mahasiswa skripsi dianggap sebagai momok yang menakutkan dan beban yang berat serta penghambat kelulusan. Hanya untuk mengerjakan skripsi yang berbobot 6 SKS, mereka membutuhkan waktu 4 semester bahkan lebih. Padahal tidak sedikit mahasiswa dapat menyelesaikan studi kesarjanaannya (bobot 140 SKS) dengan masa studi sekitar 3-4 tahun.

Ada beberapa hal yang menyebabkan mahasiswa semakin lama dalam menyelesaikan skripsi, salah satunya kecemasan yang dialami mahasiswa tersebut (Linayaningsih, 2007; Marseto,
2007; Perdana, 2011; Ardiansyah, 2011). Hasilpenelitian Perdana (2001) di Jurusan Keperawatan FK Universitas B, diketahui bahwa pada suatu angkatan didapatkan 62 mahasiswa yang menjadi responden, sebanyak 48.4\% (30) mahasiswa mengalami kecemasan ringan, 43.5\% (27 orang) mengalami kecemasan sedang, dan $8.1 \%$ (5 orang) mengalami kecemasan berat.

Kecemasan mengerjakan skripsi juga dialami mahasiswa Prodi Psikologi Universitas X Yogyakarta. Berdasarkan penelitian Ardiansyah (2011) yang dilakukan kepada 60 mahasiswa yang sedang mengerjakan skripsi diketahui terdapat 3 subjek (5 \%) yang memiliki kecemasan kategori sangat rendah, 10 subjek $(16,67 \%)$ memiliki kecemasan kategori rendah, 41 subjek $(68,33 \%)$ memiliki kecemasan kategori sedang, 5 subjek (8,33\%) memiliki kecemasan kategori tinggi, dan 1 subjek (1,67 \%) memiliki kecemasan pada kategori sangat tinggi.

Berdasarkan hasil wawancara penulis kepada 5 mahasiswa yang sedang mengambil mata kuliah seminar skripsi dan 3 mahasiswa yang sedang menyusun skripsi pada Fakultas Ilmu Sosial dan Humaniora dan Fakultas Sains dan Teknologi pada Universitas $X$ diketahui mereka merasakan adanya kecemasan. Mahasiswa masih mengeluh gelisah dan cemas ketika mene- 
mukan suatu hambatan. Para mahasiswa tersebut memiliki pikiran-pikiran yang negatif terhadap skripsi sehingga hal tersebut secara tidak langsung membuat mereka menjadi pesimis dan cemas terhadap skripsi. Pikiran-pikiran negatif tersebut mereka peroleh dari persepsi mereka terhadap beberapa kejadian atau fenomena yang mereka dapatkan baik secara langsung maupun tidak langsung mengenai hambatan-hambatan yang akan dihadapi ketika menyusun skripsi.

Kecemasan (anxiety) merupakan kekhawatiran yang kurang jelas atau tidak berdasar (Kartono, 2000). Kecemasan merupakan reaksi terhadap pengalamanpengalaman tertentu di mana reaksi tersebut dapat dilihat dari pernyataan pribadi yang diketahui dari apa yang dikatakan, bagaimana ia bertindak atau dari perubahan-perubahan psikologis yang berhubungan dengan respon (Hurlock, 1973).

Menurut Horney (Alwisol, 2008), sumber-sumber ancaman yang dapat menimbulkan kecemasan tersebut bersifat lebih umum. Penyebab dapat berasal dari berbagai kejadian di dalam kehidupan atau dapat terletak di dalam diri seseorang. Menurut Murray (Alwisol, 2008) sumber-sumber kecemasan adalah need atau kebutuhan dasar pada diri individu untuk menghindar dari terluka (harmavoidance), menghindari teracuni (infavoidance), menghindar dari disalahkan (blamavoidance) dan bermacam sumbersumber lain. Di samping ketiga need tersebut, Murray juga menyebutkan bahwa kecemasan dapat merupakan reaksi emosional pada berbagai kekhawatiran, seperti kekhawatiran pada masalah sekolah, masalah finansial, kehilangan objek yang dicintai, dan sebagainya.

Faktor yang menyebabkan adanya kecemasan pada mahasiswa yang sedang mengerjakan skripsi adalah faktor pikiran yang tidak rasional (Corey, 2009). Diungkapkan oleh Adler dan Rodman (Mutmainah, 2005) bahwa pikiran yang tidak rasional merupakan pikiran yang tidak dapat dibuktikan, menimbulkan perasaan tidak enak, dan menghalangi individu untuk berkembang dalam kehidupan sehari-hari secara efektif. Saat terjadi kecemasan bukanlah kejadian yang membuat merasa cemas, namun kepercayaan atau keyakinan tentang hal tersebut yang menjadi penyebab munculnya kecemasan

Banyak metode yang sudah digunakan untuk menurunkan kecemasan di antaranya adalah relaksasi, metode pencitraan, dan perilaku (Greenberger, 2004), teknik nafas dalam (Ghofur, 2007), dan lain-lain. Kecemasan juga dapat diturunkan melalui intervensi kognitif, seperti mengidentifikasi dan mengubah pemikiran yang menyertai rasa cemas (Greenberger, 2004). 
Menurut Greenberger (2004), pemikiran atau interpretasi yang berbeda bisa menyebabkan adanya suasana hati yang berbeda dalam situasi yang sama. Begitu seseorang mengalami satu suasana hati tertentu, suasana hati tersebut disertai dengan pemikiran-pemikiran lain yang mendukung dan memperkuat suasana hati itu. Ketika seseorang berpikir negatif, otak akan terfokus pada informasi-informasi negatif saja atau pada informasi yang mendukung karena dalam satu waktu akal manusia tidak bisa berkonsentrasi pada banyak informasi. Pada waktu yang bersamaan, otak akan menggagalkan seluruh informasi positif yang lain. Aktivitas tersebut akan memengaruhi perasaan, sikap, dan perilaku. Perasaan cemas, takut, sedih, gelisah, dan frustasi berasal dari pikiran negatif (Elfiky, 2011).

Macleod dan Moore (2000) menyatakan bahwa terapi kognitif adalah mengenai berpikir secara realistis yang kemudian disebut sebagai berpikir positif. Dapat juga dikatakan bahwa berpikir positif adalah berpikir realistis di mana berpikir realistis merupakan bentuk dari terapi kognitif. Beberapa penelitian menemukan bahwa berpikir positif mampu mengubah perilaku individu. Hal ini sebagaimana penelitian Lestari (1998) yang menemukan bahwa pelatihan berpikir positif efektif untuk mengubah sikap yang pesimis menjadi optimis serta efektif untuk menurunkan simtom depresi.
Penelitian Dwitantyanov

(2010) menemukan bahwa berpikir positif membantu mahasiswa untuk mengarahkan motivasi, kemampuan kognisi, dan mengambil tindakan yang diperlukan untuk mengerjakan tugas, mencapai tujuan, dan mengatasi tantangan akademik dengan optimal. Dengan mengubah cara berpikirnya menjadi positif, efikasi diri akademik dapat ditingkatkan, karena berpikir positif membuat individu cenderung berperasaan positif serta memandang tujuan akademik tertentu dapat diraihnya.

Sinclair (Lestari, 1998) menyatakan bahwa orang-orang yang mempunyai pikiran positif cenderung melihat hal yang positif secara lebih baik. Dengan menggunakan pikiran positif, maka akan timbul keyakinan bahwa setiap masalah akan ada jalan pemecahannya (Peale, 2009).

Berdasarkan penjelasan di atas, hipotesis yang diajukan dalam penelitian ini adalah pelatihan berpikir positif efektif untuk menurunkan kecemasan mengerjakan skripsi pada mahasiswa-mahasiswa Fakultas Ilmu Sosial dan Humaniora serta Fakultas Sains dan Teknologi Universitas $\mathrm{X}$.

\section{METODE PENELITIAN}

\section{Rancangan Eksperimen}

Penelitian ini menggunakan PretestPosttest Control Design. Pada desain ini dilakukan pengukuran sebelum (prates) 
dan sesudah (pascates) pemberian perlakuan pada dua kelompok (Seniati, dkk, 2011). Pada saat pemberian pelatihan, peneliti tidak memberitahukan kepada subjek mengenai perlakuan yang sedang subjek peroleh atau kondisi perlakuan yang sedang subjek peroleh (single blind experiment). Peneliti hanya memperlihatkan beberapa informasi jalannya eksperi- men namun tidak secara keseluruhan (Myers \& Hansen, 2002). Hal ini dilakukan dengan tujuan menghindari extraneous variable ataupun variabel sekunder yang dapat menimbulkan bias dalam eksperimen. Rancangan eksperimen dalam penelitian ini adalah sebagai berikut:

Tabel 1 Rancangan Eksperimen

\begin{tabular}{cccc}
\hline Kelompok & Prates & Perlakuan & Pascates \\
\hline Eksperimen & $O_{1 E}$ & Pelatihan Berpikir Positif & $O_{2 E}$ \\
Kontrol & $O_{1 K}$ & - & $O_{2 K}$ \\
\hline
\end{tabular}

\section{Subjek Penelitian}

Subjek penelitian ini adalah mahasiswa fakultas eksakta dan non eksakta Universitas $\mathrm{X}$ Yogyakarta, yaitu mahasiswa Fakultas Ilmu Sosial dan Humaniora serta Fakultas Sains dan Teknologi yang sedang mengerjakan skripsi. Adapun karakteristik subjek penelitian ini adalah (a) Berstatus sebagai mahasiswa Fakultas Ilmu Sosial dan Humaniora atau Fakultas Sains dan Teknologi Universitas $X$ Yogyakarta, (b) Sedang dalam proses mengerjakan skripsi, dan (c) Sudah mengambil mata kuliah skripsi 6 sks.

\section{Tabel 2. Distribusi subjek penelitian}

\begin{tabular}{|c|c|c|c|c|c|c|c|}
\hline \multicolumn{3}{|c|}{ Kelompok eksperimen } & \multicolumn{5}{|c|}{ Kelompok kontrol } \\
\hline $\begin{array}{c}\text { No. } \\
\text { subjek }\end{array}$ & $\begin{array}{l}\text { Skor } \\
\text { prates }\end{array}$ & $\begin{array}{c}\text { Skor } \\
\text { pascates }\end{array}$ & $\begin{array}{l}\text { Gain } \\
\text { score }\end{array}$ & $\begin{array}{c}\text { No. } \\
\text { subjek }\end{array}$ & $\begin{array}{l}\text { Skor } \\
\text { prates }\end{array}$ & $\begin{array}{c}\text { Skor } \\
\text { pascates }\end{array}$ & $\begin{array}{l}\text { Gain } \\
\text { score }\end{array}$ \\
\hline 1 & 144 & 86 & -58 & 1 & 109 & 94 & -15 \\
\hline 2 & 107 & 78 & -29 & 2 & 107 & 97 & -10 \\
\hline 3 & 104 & 93 & -11 & 3 & 103 & 82 & -21 \\
\hline 4 & 102 & 73 & -29 & 4 & 111 & 98 & -13 \\
\hline 5 & 106 & 83 & -23 & 5 & 114 & 95 & -19 \\
\hline 6 & 127 & 80 & -47 & 6 & 105 & 93 & -12 \\
\hline 7 & 103 & 74 & -29 & 7 & 100 & 92 & -8 \\
\hline 8 & 107 & 51 & -56 & 8 & 100 & 98 & -2 \\
\hline 9 & 112 & 82 & -30 & 9 & 118 & 117 & -1 \\
\hline 10 & 106 & 89 & -17 & 10 & 102 & 91 & -11 \\
\hline 11 & 105 & 97 & -8 & 11 & 100 & 83 & -17 \\
\hline 12 & 112 & 71 & -41 & 12 & 105 & 104 & -1 \\
\hline
\end{tabular}




\section{Metode Pengumpulan Data}

Metode pengumpulan data yang digunakan untuk mendapatkan data dalam penelitian ini berupa skala. Skala merupakan alat ukur psikologis dalam bentuk kumpulan pernyataan sikap yang disusun sedemikian rupa sehingga respon seseorang dalam pernyataan tersebut dapat diberi skor dan diinterpretasi (Azwar, 2011). Skala yang dimaksud adalah skala kecemasan menghadapi skripsi Ardiansyah (2011) yang disusun berdasarkan aspek-aspek kecemasan Calhoun dan Accocella (1990).

Skala Kecemasan Menghadapi Skripsi ini terdiri atas 39 aitem dengan koefisien alpha 0,914. Skala ini berupa pertanyaan-pertanyaan yang bersifat unfavourable dan favourable yang berkisar dari angka 1 sampai 4. Pernyataan favorable untuk jawaban Sangat Sesuai (SS) diberi skor 4, Sesuai (S) skor 3, Tidak Sesuai (TS) skor 2, dan Sangat Tidak Sesuai (STS) bernilai 1. Untuk pernyataan unfavorable, jawaban dari item yang menunjukkan Sangat Sesuai (SS) diberi skor 1, Sesuai (S) skor 2, Tidak Sesuai (TS) bernilai 3 dan Sangat Tidak Sesuai (STS) bernilai 4 .

\section{Prosedur Eksperimen}

Pelatihan berpikir positif merupakan suatu bentuk kegiatan yang sistematis, terorganisir dan terdapat sejumlah instruksi untuk berpikir positif, yaitu berpikir yang bersumber dari hal-hal yang baik atau positif sehingga pelatihan berpikir positif diharapkan dapat membantu seseorang agar memandang sesuatu hal atau peristiwa secara lebih positif dan dapat menimbulkan rasa optimisme serta perasaan-perasaan positif pada diri seseorang. Pelatihan berpikir positif disusun berdasarkan aspek-aspek berpikir positif menurut Albrecht (1980): positive expectation (harapan positif), self affirmation (afirmasi diri), non judgement talking (pernyataan yang tidak menilai), dan reality adaption (penyesuaian terhadap kenyataan). Dalam eksperimen ini pelatihan berpikir positif diberikan dalam tujuh sesi. Pemberian ketujuh sesi ini diberikan dalam waktu dua hari.

\section{Teknik Analisis Data}

Penelitian ini menghasilkan jenis data kuantitatif yang diperoleh dari skor skala kecemasan menghadapi skripsi pada saat prates dan pascates. Penelitian ini menggunakan analisis nonparametrik. Uji Hipotesis yang dilakukan dalam penelitian ini menggunakan dua teknik, yaitu Wilcoxon Range Test dan Mann Witney U. Teknik analisis Wilcoxon Range Test digunakan untuk menguji satu kelompok subjek yang sama. Dalam penelitian ini data yang diuji menggunakan Wilcoxon Range Test adalah skor prates kelompok eksperimen dengan skor pascates kelom- 
pok eksperimen. Uji Mann Whitney $U$ merupakan teknik statistik non parametrik yang digunakan untuk menguji dua kelompok yang berbeda (Suseno, 2011). Data yang diuji dengan teknik Mann Whitney $U$ pada penelitian ini adalah gain score antara kelompok eksperimen dan kelompok kontrol. Proses analisis data untuk uji hipotesis ini dibantu dengan SPSS (Statistical Package Social Science) versi 16.0 for windows.

\section{HASIL PENELITIAN}

Uji statistik dilakukan dengan teknik analisis statistik non parametrik Wilcoxon Range Test menghasilkan nilai $z$ sebesar 3.064 dengan nilai $p=0,002 \quad(p<0,05)$ sehingga hipotesis pelatihan berpikir positif efektif untuk menurunkan kecemasan mengerjakan skripsi pada mahasiswa diterima.

Tabel 3. Hasil Analisis Wilcoxon Signed-Rank Test

\begin{tabular}{lrr}
\hline & \multicolumn{2}{c}{ Test Statistics } \\
\cline { 2 - 3 } & $\begin{array}{l}\text { post_Keksperimen- } \\
\text { pre_Keksperimen }\end{array}$ & keterangan \\
\cline { 2 - 3 } Z & $-3.064^{\mathrm{a}}$ & \\
Asymp. Sig. (2-tailed) & .002 & Ada perbedaan $(\mathrm{P}<0.05)$ \\
\hline
\end{tabular}

Selanjutnya, uji statistik dilakukan dengan teknik analisis statistik non parametrik Mann Whitney $U$ menghasilkan nilai $z$ sebesar -3.152 dengan nilai $p=0,002 \quad(p<0,05) \quad$ sehingga hipotesis diterima, yaitu mahasiswa yang mengikuti pelatihan berpikir positif cenderung memiliki tingkat kecemasan yang lebih rendah dibandingkan mahasiswa yang tidak mengikuti pelatihan berpikir positif. Kelompok eksperimen yang diberi pelatihan berfikir positif memiliki kecemasan mengerjakan skripsi yang lebih rendah dibanding dengan kelompok kontrol yang tidak diberi pelatihan, hal ini terlihat dari gain score antara kelompok eksperimen dan kelompok kontrol. 
Tabel 4. Hasil Analisis Mann Whitney $U$

\begin{tabular}{lll}
\hline & \multicolumn{2}{c}{ Test Statistics $^{\mathbf{b}}$} \\
\cline { 2 - 3 } & \multicolumn{1}{c}{ Gain score } & Keterangan \\
\hline Mann-Whitney U & 17.500 & \\
Wilcoxon W & 95.500 & \\
Z & -3.152 & Ada Perbedaan \\
Asymp. Sig. (2-tailed) & $.002(\mathrm{p}<0,5)$ & \\
Exact Sig. [2*(1-tailed Sig.)] & $.001^{\mathrm{a}}$ & \\
\hline
\end{tabular}

\section{PEMBAHASAN}

Peneitian ini bertujuan untuk mengetahui efektivitas pelatihan berpikir positif untuk menurunkan kecemasan mahasiswa dalam mengerjakan skripsi. Hasil penelitian menunjukkan bahwa pelatihan berpikir positif efektif dalam menurunkan kecemasan dalam mengerjakan skripsi. Hasil penelitan ini mendukung pendapat Greenberger (2004) bahwa pemikiran atau interpretasi atas suatu realitas menyebabkan adanya suasana hati tertentu. Pelatihan berpikir positif menurunkan kecemasan dalam diri mahasiswa yang sedang mengerjakan skripsi.

Pelatihan berpikir positif sendiri yang disusun berdasarkan aspek-aspek berpikir positif efektif untuk menurunkan kecemasan mengerjakan skripsi pada mahasiswa. Berpikir positif sendiri memiliki empat aspek, yaitu positive expectation (harapan positif), self affirmation (afirmasi diri), non judgement talking (pernyataan yang tidak menilai), dan reality adaptation (penyesuaian diri terhadap kenyataan).

Pertama: Aspek Reality Adaptation. Reality adaptation (penyesuaian diri terhadap kenyataan) adalah mengakui kenyataan dengan segera menyesuaikan diri, menjauhkan diri dari penyesalan, frustrasi dan menyalahkan diri sendiri, serta menerima masalah dan mencoba menghadapinya (Albrecht, 1992). Seseorang yang dapat menerima berbagai kenyataan baik yang diinginkan ataupun tidak. Dengan segera menyesuaikan diri terhadap kenyataan tersebut, individu akan cenderung memiliki jiwa yang sehat dibandingkan dengan seseorang yang tidak dapat menerima kenyataan dan cenderung menyalahkan diri sendiri. Allport (Schultz,1991) menyatakan bahwa seseorang yang sehat tidak memaksakan bahwa sesuatu harus sesuai dengan keinginan-keinginannya. Seseorang yang sehat adalah seseorang yang menerima realitas apa adanya.

Saat seseorang mengalami kegagalan atau menghadapi kenyataan yang tidak sesuai dengan harapan sebenarnya memiliki dua pilihan, yaitu berpikir realistis 
untuk tetap bertahan menerima kenyataan tersebut dan segera menyesuaikan diri atau berpikir tidak realistis dengan mengingkari kenyataan dan hanya melakukan penyesalan, menyalahkan diri sendiri bahkan menghindar atau lari dari kenyataan dan frustrasi. Individu yang memiliki pola pikir positif dapat menyesuaikan diri dengan kenyataan secara objektif dan tepat.

Berpikir positif merupakan cara berpikir yang bersumber dari hal-hal yang baik yang mampu memotivasi seseorang untuk membangun kehidupan yang lebih baik. Selain itu, berpikir positif juga dapat mengarahkan dan membimbing seseorang untuk meninggalkan hal-hal negatif yang bisa melemahkan semangat perubahan dalam jiwanya (Asmani, 2009). Individu yang dapat mengelola pikiran positifnya tidak hanya sekedar menerima kenyataan, tetapi dapat menyikapi kenyataan yang sudah terjadi dengan bijaksana dan fokus.

Aspek reality adaptation diturunkan menjadi sesi pelatihan Life is never flat. Sesi ini diberikan pada hari pertama. Pada sesi ini peserta diajak untuk melihat dan menyadari bagaimana pola pikir peserta selama ini dalam menghadapi kenyataan yang berkaitan dengan skripsi dengan melihat gaya penjelasan pemikiran otomatis yang ada di dalam diri peserta. Pemikiran otomatis adalah pemikiran yang muncul begitu saja (spontan) di benak kita tanpa adanya perencanaan atau sengaja memikirkannya dengan satu cara tertentu (Greenberger, 2004).

Pemikiran otomatis seseorang dapat dilihat dari gaya penjelasan (explanatory style) yang ia gunakan. Explanatory style merupakan penjelasan-penjelasan yang biasa dikatakan kepada diri sendiri tentang mengapa kejadian-kejadian itu bisa terjadi (Seligman, 2008). Gaya penjelasan terdiri atas dua tipe, yaitu gaya penjelasan optimis dan gaya penjelasan pesimis. Gaya penjelasan yang optimis menghentikan ketidakberdayaan, sedangkan gaya penjelasan yang pesimis menyebarluaskan ketidakberdayaan pada diri, yaitu respon menyerah dan percaya bahwa apapun yang dilakukan tidak ada artinya atau menyalahkan diri sendiri. Gaya penjelasan memiliki tiga dimensi, yaitu permanensi (waktu), kemudahan menyebar, dan personalisasi (Seligman, 2008). Dari ketiga dimensi tersebut peserta dapat menganalisis gaya penjelasan pemikiran otomatis yang ada didalam dirinya.

Individu yang memiliki pola pikir positif akan cenderung memiliki gaya penjelasan yang optimis, karena optimisme merupakan salah satu dimensi berpikir positif. Optimisme adalah evaluasi umum seseorang terhadap masa depan yang merefleksikan kepercayaan terhadap munculnya hal-hal yang baik dan berkurangnya hal-hal yang buruk (Caprara 
\& Steca, 2005). Individu tersebut dapat menyesuaikan diri dengan kenyataan, bersikap realistis dan mencari alternatif lain ketika menghadapi suatu kenyataan yang tidak sesuai dengan harapan sehingga perasaan-perasaan negatif seperti kecemasan pada diri akan berkurang. Dengan demikian peserta diharapkan secara kognitif mengerti bahwa gaya penjelasan pemikiran otomatis dapat memengaruhi bagaimana seseorang menghadapi kenyataan yang ada atau beradaptasi.

Dalam proses pelatihan, peserta diminta untuk mengerjakan lembar kerja pencatatan pikiran otomatis. Pada lembar kerja ini peserta menganalisis gaya penjelasan pemikiran otomatis yang muncul ketika peserta menghadapi kenyataan yang tidak diharapkan saat mengerjakan skripsi, apakah selama ini lebih banyak menggunakan gaya penjelasan optimis atau pesimis. Melalui pengerjaan lembar kerja pada sesi ini dapat diungkap sisi kognitif dan afektif peserta tentang bagaimana selama ini para peserta beradaptasi terhadap realitas yang ada dalam hal ini adalah beradaptasi dengan hambatanhambatan yang mereka temukan selama mengerjakan skripsi. Para peserta juga terstimulasi secara kognitif dan afektif bahwa didalam proses pencapaian terdapat sebuah tantangan yang memang harus dihadapi.

Ketika seseorang dapat menerima kenyataan dan memiliki gaya penjelasan yang optimis dalam menghadapi suatu kenyataan yang ada baik kenyataan yang diharapkan atau tidak diharapkan, maka orang tersebut lebih mampu beradaptasi atau menyesuaikan diri dengan kenyataan secara lebih positif. Karena pikiran lebih terfokus pada bagaimana mencari alternatif untuk menyesuaikan diri pada kenyataan agar mampu bertahan dan menjadi lebih baik sehingga kecemasan pada diri berkurang. Sementara orang yang tidak bisa menerima kenyataan dan memiliki gaya penjelasan yang pesimis cenderung merasakan keprihatinan, frustrasi dan mencela diri sendiri. Hal ini karena pikiran lebih terfokus pada pengingkaran kenyataan atau menghindar dari kenyataan. Ketika seseorang menghindari satu situasi yang sulit atau tidak diinginkan dan menjadi sumber kecemasan, maka orang tersebut semakin cemas di masa mendatang. Kecemasan dapat diatasi dengan cara belajar untuk melakukan pendekatan terhadap situasi atau orang yang dihindari dan mengatasinya saat cemas merupakan satu cara yang kuat dan tahan lama untuk menghilangkan kecemasan (Greenberger, 1995). Melalui sesi Life is never flat ini, peserta terstimulasi secara kognitif, afektif, dan psikomotorik untuk beradaptasi dengan segala hal yang berkaitan dengan skripsi sehingga kecemasan menurun. Berdasarkan pemaparan di atas dapat disimpulkan bahwa sesi Reality Adaptation pada pelatihan berpikir positif 
mampu menurunkan kecemasan pada mahasiswa yang sedang mengerjakan skripsi.

Kedua: Aspek non-judgement talking (pernyataan yang tidak menilai). Menurut Albrecht (1992), non-judement talking merupakan suatu pernyataan lebih menggambarkan diri dari pada penilaian keadaan, bersifat luwes, dan tidak fanatik dalam berpendapat. Pernyataan ini dimaksud sebagai pengganti pada saat seseorang cenderung memberikan pernyataan yang negatif terhadap suatu hal.

Saat melihat atau menghadapi sesuatu secara sadar maupun tidak sadar individu memberikan penilaian terhadap apa yang dilihatnya. Memberikan penilaian itu penting karena penilaian merupakan perwujudan dari cara pandang individu terhadap suatu situasi atau seseorang. Penilaian tersebut juga terbentuk menjadi label atau citra diri terhadap sesuatu ataupun seseorang. Sebuah penilaian yang muncul dari dalam diri individu memang terlihat secara spontan dan sederhana. Selain itu memberikan penilaian hanya sebagian kecil dari proses kognitif individu, namun individu harus berhati-hati atau bijaksana dalam memberikan sebuah penilaian terhadap suatu hal atau seseorang.

Satu respon dari dalam diri yang bisa melumpuhkan diri adalah menganggap sesuatu sebagai bencana, yaitu merenungi peristiwa-peristiwa yang buruk secara destruktif. Semakin banyak seseorang merenungi peristiwa buruk tersebut, maka peristiwa tersebut akan dirasa semakin berat dan semakin besar akibat-akibat yang mungkin muncul. Selain itu semakin sering seseorang menganggap sesuatu sebagai bencana, maka hal tersebut menimbulkan distraksi dalam berpikir dan menurunkan semangat sehingga seseorang akan kehabisan tenaga dan cemas (Stolz, 2005).

Penilaian negatif yang muncul didukung oleh pemikiran-pemikiran negatif lain yang mendukung penilaian tersebut. Otak menjadi terfokus pada informasiinformasi negatif saja atau pada informasi yang mendukung karena dalam satu waktu akal manusia tidak bisa berkonsentrasi pada banyak informasi. Pada waktu yang bersamaan, otak menggagalkan seluruh informasi positif yang lain (Elfiky, 2011). Hal inilah yang menyebabkan distorsi kognitif, seseorang tidak akan bisa berfikir dengan jernih dan seakan-akan tidak bisa menemukan jalan keluar. Suatu hal kecil yang sudah dianggap sebagai suatu bencana terlihat begitu besar dan sulit. Individu merasakan kecemasan, frustrasi, dan merasa dirinya tidak mampu untuk menghadapinya. Oleh karena itu penilaian-penilaian negatif atau judgement negatif di dalam diri perlu dihentikan agar tidak memengaruhi diri individu.

Skripsi yang dirasakan peserta merupakan sesuatu yang berat dan 
menimbulkan kecemasan. Hal tersebut terjadi karena selama ini peserta menilai skripsi secara negatif. Oleh karena itu peserta perlu menghentikan judgement tersebut dengan pemikiran alternatif (pemikiran yang lebih positif) sehingga akan memunculkan penilaian yang lebih positif. Melalui materi tersebut peserta diharapkan secara kognitif dapat memahami pentingnya menghentikan judgement-judgement negatif di dalam diri.

Pada sesi pelatihan stop overgeneralization ini peserta dilatih untuk menghentikan penilaian negatif agar tidak menjadi distraksi kognitif dan merugikan diri peserta dengan cara mencari pemikiran alternatif untuk mengganti pemikiran negatif sebelumnya. Pemikiran alternatif seringkali lebih positif daripada pemikiran otomatis awal. Pemikiran alternatif merupakan upaya untuk memahami semua informasi yang ada. Dengan adanya informasi tambahan atau pandangan yang lebih luas maka interpretasi individu terhadap suatu peristiwa bisa berubah (Greenberger, 2004).

Ketika seseorang memiliki penilaian negatif terhadap suatu hal atau peristiwa, secara otomatis orang tersebut selalu memikirkan hal-hal negatif yang mungkin dialami dan mengurungnya dalam perasaan-perasaan negatif seperti kecemasan yang pada akhirnya akan berdampak pada perasaan dan perilaku. Peristiwa tersebut dirasa semakin berat karena penilaian yang diciptakan sendiri. Individu juga mengalami distorsi kognitif karena otak akan terfokus pada informasi negatif atau hal-hal yang mendukung penilaian tersebut sehingga individu merasa kesulitan dalam menemukan jalan keluar. Individu merasakan kecemasan, frustrasi, dan tidak mampu untuk menghadapinya. Saat peserta menilai skripsi itu sulit dan berat, maka secara tidak langsung peserta hanya menerima informasi-informasi yang mendukung penilaiannnya tersebut, yaitu mencari penguatan bahwa skripsi itu memang berat dan sulit sehingga energi dan semangat dari dalam diri peserta turun dan cemas. Peserta merasa bahwa dirinya tidak mampu untuk menyelesaikan skripsi karena kesulitan dalam menemukan jalan keluar sehingga peserta merasakan perasaan negatif seperti cemas.

Melalui sesi stop overgeneralization ini peserta diharapkan dapat terstimulasi secara kognitif, afektif, dan psikomotorik untuk menilai skripsi secara lebih positif. Sesi ini juga diharapkan dapat menstimulus peserta untuk mampu mengelola penilaian pikiran sehingga dapat beradaptasi secara lebih positif. Dari pemaparan di atas dapat disimpulkan bahwa sesi nonjudgement talking pada pelatihan berfikir positif mampu menurunkan kecemasan pada mahasiswa yang sedang mengerjakan skripsi.

Ketiga: Aspek Positive Expectation. Aspek berpikir positif selanjutnya adalah 
harapan positif yang diturunkan menjadi sesi pelatihan My dreams come true. Menurut Albrecht (1992), harapan positif adalah bila melakukan sesuatu lebih memusatkan perhatian pada kesuksesan, optimis, pemecahan masalah, dan menjauhkan diri dari rasa takut akan kegagalan serta selalu menggunakan kata-kata yang mengandung harapan seperti "saya dapat melakukannya". Seseorang yang memiliki harapan, impian atau cita-cita cenderung lebih positif dalam memahami sesuatu. Hal ini terjadi karena dibalik impian pasti ada emosi yang mendasarinya. la melakukan sesuatu dengan lebih memusatkan perhatian pada kesuksesan, optimis, pemecahan masalah, dan selalu menggunakan kata-kata yang mengandung harapan seperti "saya dapat melakukannya".

Menurut Dornan dan Maxwell (Asmani, 2009), keberhasilan seseorang ditentukan oleh sikap orang itu sendiri. Perbedaan antara orang yang sukses dan orang yang yang tidak sukses adalah kehidupan orang yang sukses diatur dan dibayangi oleh pikiran-pikiran saat-saat terbaik mereka, rasa optimis, dan pengalaman terbaik. Sedangkan kehidupan orang-orang yang tidak sukses diatur dan dibayangi oleh rasa ragu serta kegagalan-kegagalan mereka dimasa lalu.

Pada sesi ini peserta dibantu mengenali dan memahami harapan atau cita-cita di dalam diri melalui materi tentang tingkatan keinginan berdasarkan intensitas emosi dan kebermaknaannya, dalam hal ini impian termasuk kedalam passion. Seseorang yang sudah menemukan dan memiliki passion dengan senang hati melakukan aktivitas yang berhubungan dengan passion nya tersebut. la selalu bersemangat, optimis, dan pantang menyerah dalam melakukannya sehingga muncul motivasi untuk melakukan dan mencapai hal-hal yang positif.

Motivasi yang mulai terinternalisasi dalam diri mendorong individu untuk membangun kehidupan yang lebih baik. Individu lebih memfokuskan pada hal yang lebih positif atau hal-hal yang mendukung untuk mencapai harapan atau kesuksesan. Selanjutnya, secara tidak langsung individu diarahkan untuk meninggalkan pikiran-pikiran yang negatif dimana pikiran-pikiran negatif tersebut yang menstimulasi munculnya emosiemosi negatif, seperti kecemasan. Materi ini diharapkan dapat menstimulus sisi kognitif peserta untuk mengerti pentingnya sebuah impian dalam hal ini adalah passion. Peserta juga diharapkan dapat terstimulus secara kognitif dan afektif untuk menilai harapan atau mimpi yang selama ini mereka alami adalah benarbenar harapan yang mereka ingin capai atau hanyalah sebuah keinginan yang sementara bahkan hanya sebuah khayalan. 
Peserta kemudian mengerjakan lembar kerja passion test. Peserta diminta menuliskan daftar impian minimal 10 passion kemudian passion tersebut diurutkan berdasarkan prioritas dimulai dengan angka 1. Namun pada lembar kerja passion test sudah tertulis "mengerjakan skripsi" pada urutan pertama. Hal ini dimaksudkan agar peserta menyadari bahwa skripsi adalah sebuah jembatan yang harus dilalui untuk meraih impian. Skripsi tidak dapat diabaikan oleh peserta jika peserta ingin meraih impiannya, sehingga skripsi memang harus diselesaikan dan menjadi prioritas utama untuk saat ini. Setelah passion diurutkan, peserta diminta untuk memilih tiga passion yang paling penting. Peserta menentukan syarat tercapainya ketiga passion yang sudah dipilih kemudian menentukan score passion dilihat dari berapa syarat yang sudah terpenuhi saat ini. Saat score passion sudah diketahui, peserta diminta menuliskan skor yang dibutuhkan untuk mencapai atau melengkapi score passion kemudian peserta merencanakan tindakan untuk mencapai passion (passion to action). Lembar kerja ini menyadarkan peserta tentang pengerjaan skripsi mereka, apakah saat ini pengerjaan skripsi sudah menjadi salah satu passion dan prioritas utama peserta atau belum. Peserta juga terstimulasi secara kognitif dan psikomotorik untuk menyelaraskan perilaku dengan harapan yang dimiliki.
Saat seseorang memiliki harapan positif atau dalam hal ini adalah passion, ia cenderung fokus pada hal-hal yang positif. Pikiran terfokus pada proses pencapaian dan kesuksesan dalam meraih harapan sehingga emosi-emosi positif pada diri bermunculan seperti bahagia, percaya diri, optimis, dan semangat. Emosi-emosi tersebut menumbuhkan motivasi untuk melakukan dan mencapai hal-hal yang positif. Secara tidak langsung individu diarahkan untuk meninggalkan pikiran-pikiran yang negatif di mana pikiran-pikiran negatif tersebut yang menstimulus munculnya emosi-emosi negatif, seperti kecemasan yang dapat melemahkan semangat perubahan pada diri seseorang. Hal ini sesuai dengan pernyataan Asmani (2009) bahwa berpikir positif merupakan cara berpikir yang bersumber dari hal-hal yang baik yang mampu memotivasi seseorang untuk membangun kehidupan yang lebih baik.

Seseorang yang sudah menemukan dan memiliki harapan dengan senang hati melakukan aktivitas yang berhubungan dengan harapannya tersebut serta memiliki motivasi tinggi untuk meraihnya. Pada sesi ini peserta diarahkan untuk menyadari bahwa skripsi adalah suatu hal yang berhubungan dengan harapan atau impiannya. Skripsi merupakan salah satu jalan yang harus ditempuh dan diselesaikan untuk meraih harapan-harapan yang dimiliki sehingga peserta akan 
melihat skripsi secara lebih positif. Peserta akan termotivasi untuk menyelesaikan skripsi, selalu bersemangat dan pantang menyerah ketika menemukan hambatan saat mengerjakan skripsi sehingga kecemasan menurun.

Harapan positif yang dimiliki peserta secara tidak langsung akan mengarahkan perilaku peserta untuk melakukan halhal positif dan meraih harapannya tersebut, seperti mengerjakan skripsi dengan penuh semangat dan optimis. Scheier dan Carver (1993) menyatakan bahwa berpikir positif melibatkan ekspektasi positif bagi masa depan seseorang dimana ekspektasi tersebut terbangun dalam implikasi tingkah laku atau tindakan seseorang dan ekspektasi tersebut sejalan dengan tindakan mereka. Semakin seseorang terlibat sepenuhnya dengan berbagai aktivitas yang dianggap penting dan relevan bagi dirinya serta aktivitas tersebut membuat senang maka orang tersebut akan sehat secara psikologis (Schultz, 1991). Melalui sesi ini peserta secara kognitif dan afektif dapat mengerti arti pentingnya sebuah harapan positif. Peserta juga akan terstimulus secara kognitif dan psikomotorik untuk menyelaraskan perilaku dengan harapan yang dimiliki, selain itu sesi ini dapat menumbuhkan motivasi peserta untuk mengerjakan skripsi dan mencapai harapannya. Berdasarkan pemaparan di atas dapat disimpulkan bahwa sesi Positive Expectation pada pelatihan berpikir positif mampu menurunkan kecemasan mengerjakan skripsi pada mahasiswa.

Keempat: Aspek Self Affirmation. Aspek berpikir positif yang terakhir adalah afirmasi diri, yaitu memusatkan perhatian pada kekuatan diri sendiri secara lebih positif dengan dasar pemikiran bahwa setiap orang sama berartinya dengan orang lain (Albrecht,1992). Seseorang yang memiliki pikiran positif yakin terhadap dirinya sendiri serta pada orang lain. Melalui pikiran positif seseorang terdorong untuk melakukan suatu hal yang baru dan menggunakan kesempatan yang ada (Dornan \& Maxwell, dalam Asmani 2009).

Pada dasarnya setiap orang memiliki kelebihan dan kekurangan masingmasing, namun yang sering menjadi masalah adalah ketika seseorang tidak dapat memahami dirinya sendiri dan kemudian merasa rendah diri, minder, dan tidak percaya diri karena kekurangan yang dimiliki. Pikiran hanya terfokus pada hal-hal negatif yang ada didalam diri hingga seolah-olah tidak ada hal yang positif atau kelebihan yang dimiliki. Ketika seseorang sudah melihat dirinya secara negatif, maka orang tersebut merasa pesimis dan tidak berdaya dalam menghadapi lingkungan di luar dirinya. Kecemasan dapat datang dari perasaan tidak mampu menghadapi tantangan lingkungan, tidak adanya kepastian 
tentang apa yang dihadapi dan adanya rasa kurang percaya diri (Hurlock, 1973).

Afirmasi diri merupakan penguatan terhadap diri pribadi secara lebih positif atas tindakan-tindakan yang dilakukan, memusatkan perhatian pada kekuatan diri dan melihat diri secara positif. Kepercayaan terhadap diri sendiri selalu dibangun dengan menggunakan pola-pola berpikir positif. Seseorang yang melakukan afirmasi diri percaya bahwa dalam diri terkandung potensi-potensi atau kemampuan-kemampuan yang dapat dikembangkan ke arah yang lebih maju dan lebih positif. Kekurangan di dalam diri tidak menjadi penghalang dalam mencapai tujuan hidupnya, namun ia memiliki keyakinan bahwa kekurangan bisa diubah menjadi kelebihan atau kekurangan bisa menjadi motivasi diri untuk menjadi lebih baik.

Aspek self affirmation diturunkan menjadi sesi Yes,l can! pada pelatihan berpikir positif. Pada sesi ini peserta diajak untuk mengerti dan menyadari pentingnya meyakini kekuatan yang ada di dalam diri dan bagaimana keyakinan dapat memengaruhi perilaku. Seseorang yang melihat dirinya secara lebih positif, yaitu meyakini kekuatan atau kelebihankelebihan yang ada di dalam dirinya cenderung lebih optimis dan percaya diri. Keyakinan terhadap sesuatu hal dapat menjadi faktor penentu emosi, yang menghasilkan perilaku. Hal ini terjadi karena ketika seseorang memiliki suatu keyakinan terhadap suatu hal, maka pikiran-pikiran menjadi fokus terhadap informasi-informasi yang mendukung keyakinannya tersebut. Jadi saat seseorang memiliki keyakinan terhadap kelebihan dan potensi diri, maka orang tersebut merasakan emosi positif sehingga emosi negatif pada diri seperti kecemasan akan berkurang.

Ketika peserta menyadari dan meyakini kekuatan atau kelebihan yang ada di dalam diri, peserta menjadi cenderung lebih percaya diri dan optimis dalam melakukan suatu hal termasuk dalam pengerjaan skripsi. Peserta menyadari bahwa dirinya memiliki kemampuan untuk mengerjakan skripsi dan mampu menghadapi segala hambatannya. Hal ini secara tidak langsung juga membentuk peserta untuk menjadi motivator bagi dirinya sendiri dalam mengerjakan skripsi. Pikiran peserta akan lebih fokus pada halhal yang positif sehingga emosi-emosi negatif seperti kecemasan akan berkurang. Lembar kerja pada sesi ini lebih mengarah pada self report peserta, yaitu mengungkapkan kelebihan atau potensipotensi yang dimiliki peserta kemudian meneguhkannya melalui teknik afirmasi diri.

Saat seseorang melihat dirinya secara lebih positif, meyakini kekuatan atau kelebihan yang ada di dalam dirinya, maka orang tersebut menjadi lebih 
percaya diri dan optimis dalam menghadapi suatu hal. Keyakinan yang positif terhadap dirinya sendiri memunculkan emosi positif yang selanjutnya akan memengaruhi perilaku. Rasa percaya diri dan optimis pada diri mengarahkan perilaku seseorang untuk melakukan hal yang jauh lebih positif dan adaptif sehingga emosi negatif seperti kecemasan akan berkurang. Dari pemamparan di atas dapat disimpulkan bahwa sesi self affirmation pada pelatihan berpikir positif mampu menurunkan kecemasan mengerjakan skripsi pada mahasiswa.

Faktor lain yang memengaruhi penurunan kecemasan menghadapi skripsi pada mahasiswa antara lain adalah karakteristik subjek yang cenderung homogen dan memiliki masalah yang relatif sama sehingga menyebabkan subjek lebih terbuka dan kompak. Subjek dapat mengikuti seluruh sesi pelatihan dengan kondusif dan mau mengerjakan setiap lembar kerja yang diberikan, hal ini dapat dilihat dari hasil observasi selama pelatihan. Building rapport yang dilakukan trainer cukup baik sehingga hubungan trainer dan subjek selama pelatihan terjalin dengan baik. Trainer juga mampu menyampaikan materi dengan santai namun serius sehingga materi yang disampaikan mudah dipahami peserta dan komunikasi diantara keduanya cukup baik atau komunikatif. Subjek pelatihan tidak merasa ragu dan lebih mampu untuk membagikan pendapat serta masalahnya kepada trainer dan peserta lain. Ruangan yang nyaman dan lingkungan yang kondusif, tidak bising juga memengaruhi diterimanya hipotesis pada penelitian ini.

Pengaruh pelatihan berpikir positif dalam menurunkan kecemasan pada mahasiswa yang sedang mengerjakan skripsi juga dapat dilihat dari lembar evaluasi pelatihan yang telah diisi oleh peserta pada akhir pelatihan. Pada lembar evaluasi tersebut dapat dilihat bahwa para peserta merasa lebih tenang dan optimis untuk segera menyelesaikan skripsi mereka. Peserta menjadi sadar bagaimana pola pikir mereka selama ini ketika menghadapi suatu peristiwa yang tidak sesuai dengan harapannya dalam hal ini adalah hambatan skripsi. Melalui pelatihan ini peserta menjadi lebih paham bagaimana cara untuk berpikir positif sehingga perasaan negatif seperti kecemasan dapat berkurang.

Kelemahan penelitian ini adalah peneliti memberikan pascates secara langsung di akhir sesi pelatihan. Hal ini menimbulkan bias dalam pengisian skala karena beberapa keterampilan yang diajarkan pada pelatihan membutuhkan waktu dan proses pengendapan kognitif untuk mempraktekkannya seperti pada sesi stop overgeneralization. Pada sesi ini peserta diajarkan untuk mengganti pemikiran atau judgement-judgement negatif yang muncul ketika peserta 
menghadapi suatu peristiwa yang tidak sesuai degan harapannya seperti hambatan skripsi dengan pemikiran alternatif yang lebih positif. Hal ini membutuhkan waktu dan proses pengendapan kognitif untuk mempraktekkan dalam kehidupan masing-masing peserta sehingga pascates sebaiknya tidak diberikan pada saat itu juga.

\section{SIMPULAN DAN SARAN}

\section{Simpulan}

Berdasarkan hasil analisis dari data yang diperoleh dalam penelitian ini, dapat disimpulkan bahwa pelatihan berpikir positif efektif untuk menurunkan kecemasan mengerjakan skripsi pada mahasiswa. Mahasiswa yang mengikuti pelatihan berpikir positif mengalami penurunan tingkat kecemasan yang lebih signifikan dibanding mahasiswa yang tidak mengikuti pelatihan berpikir positif.

\section{Saran}

Berdasarkan kesimpulan yang telah dipaparkan, peneliti mengajukan saran sebagai berikut. Pertama: saran kepada subjek penelitian. Para peserta diharapkan dapat mengembangkan lebih lanjut materi yang sudah didapatkan dalam pelatihan dan mengaplikasikannya dalam kehidupan sehari-hari karena pelatihan ini dinilai cukup efektif dalam menurunkan kecemasan mahasiswa yang sedang mengerjakan skripsi.

Kedua: saran kepada peneliti selanjutnya. Penelitian tentang kecemasan mengerjakan skripsi masih perlu dikembangkan lagi. Peneliti selanjutnya dapat melihat dan menggali dari faktorfaktor lain yang menyebabkan munculnya kecemasan pada diri mahasiswa. Hal ini diharapkan dapat membantu mahasiswa dalam mengatasi kecemasannya terutama mahasiswa yang sedang mengerjakan skripsi, karena mahasiswa yang sedang mengerjakan skripsi mengalami kecemasan yang sedikit banyak berpengaruh dalam proses pengerjaan skripsi. Selain itu, peneliti juga menyarankan agar peneliti selanjutnya mencermati alat ukur yang digunakan, apakah terdapat itemitem yang membutuhkan pengendapan atau waktu dan proses kognitif atau tidak. Jika terdapat item yang membutuhkan pengendapan kognitif, maka pascates sebaiknya dilakukan selang beberapa hari setelah perlakuan diberikan agar tidak terjadi bias dalam pengisian alat ukur tersebut.

Ketiga: saran kepada institusi. Pelatihan ini dapat dijadikan alternatif intervensi untuk mengurangi kecemasan mahasiswa yang sedang mengerjakan skripsi. Hal ini di karenakan penelitian ini terbukti efektif dalam mengurangi kecemasan mahasiswa yang sedang mengerjakan skripsi. 


\section{DAFTAR PUSTAKA}

Abidin, Z. (2006). Pendekatan kualitatif pada skripsi Mahasiswa UNDIP Tahun 2006. Jurnal Psikologi Universitas Diponegoro, 2 (3).

Albrecht, K. (1980). Brain power. USA: Prentice Hall.

Ardiansyah, R. (2011). Hubungan adversity quoetient dengan kecemasan menghadapi skripsipada Mahasiswa Program Studi Psikologi UIN Sunan Kalijaga Yogyakarta. Skripsi. Yogyakarta: UIN Sunan Kalijaga Yogyakarta.

Asmani, J.M.(2009). The law of positive thinking. Yogyakarta:Garailmu

Azwar, S. (2011). Reliabilitas dan validitas. Yogyakarta:PustakaPelajar

Calhoun, J.F and Acocella, J.R. (1990). Psychology of adjusment and human relationship. New York: McGraw Hill Book Company

Caprara, G.V. \& Steca (2005). Affective and social self-regulatory efficacy beliefs as determinants of positive thinking and happiness. Europan Psychologist, 10.

Christianai, dkk. (2000). Hubungan persepsi tentang menopause dengan tingkat kecemasan pada wanita yang menghadapi menopause. Jurnal Psikologi Universitas Gadjah Mada, 2, 96-100.
Dewi, E. (2008). Perbedaan kecemasan menghadapi spmb antara siswa kelas akselerasi dengan kelas reguler.Jurnal Keberbakatan dan Kreativitas, 2 (1), 55-65.

Dwitantyanov, A. Dkk. (2010). Pengaruh terapi berpikir positif pada efikasi diri akademik mahasiswa (studi eksperimen pada Mahasiswa Fakultas Psikologi UNDIP Semarang). Jurnal Psikologi Undip, 8 (2): 135144.

Elfiky, I. (2009). Terapi berpikir positif. Jakarta: Penerbit Zaman.

Ghofur, A. (2007). Pengaruh teknik nafas dalam terhadap perubahan tingkat kecemasan pada ibu persalinan kala i di pondok bersalin ngudi saras trikilan kali Jambe Sragen. Jurnal Kesehatan Surya Medika Yogyakarta. (http://www.skripsi stikes.wordpress.com)

Greenberger, D. (1995). Manajemen pikiran. Bandung: Penerbit Kaifa

Gunawan, A. (2009). Quantum Life Transformation. Jakarta: Penerbit Gramedia.

Hidayah, R. (2004). Pengaruh ayat-ayat alqur'an terhadap kecemasan siswa dalam menghadapi tes. Psikodinamik, 6 (2), 24-36.

Hurlock, E. (1973). Adolescent development. Tokyo: McGraw Hill 
Latipun. (2008). Psikologi eksperimen. Malang: UMM Press

Lazarus, R.S. (1969). Patterns of adjusment and human effectiveness. Tokyo: McGraw Hill Company.

Lestari, A. (1998). Pelatihan berpikir positif untuk menangani sikap pesimis dan gangguan depresi. Jurnal Psikologi, (2): 1-9

Linayaningsih, F. (2007). Kecemasan Pada Mahasiswa Fakultas Psikologi Universitas Katolik Soegija Pranata Dalam Mengerjakan Skripsi. Skripsi. Semarang: Universitas Soegijapranata.

Marseto, B. (2007). Hubungan berpikir positif dengan kecemasan mengerjakan skripsi pada Mahasiswa Fakultas Ekonomi Universitas Islam Indonesia. Skripsi. Yogyakarta: Universitas Islam Indonesia

Mcleod, A.K. (2000). Positive thinking revisited: positive cognitions, wellbeing and mental health. Clinical Psychology and Psychoterapy, 7, 110.

Munandar, A.S. (2008). Psikologi industri dan organisasi. Jakarta: UI Press

Mutmainah. (2005). Hubungan antara kecemasan menghadapi tesdengan optimisme, religiusitas, dan dukungan sosial. tesis. Yogyakarta: Universitas Gadjah Mada
Myers, A. \& Hansen, C. (2002). Experimental psychology $5^{\text {th }}$ edition. USA: Wadsworth Group

Peale, N. (2009). Kekuatan berpikir positif. Yogyakarta: Ragam Media

Perdana, P. (2011). Hubungan tingkat kecemasan dengan motivasi mahasiswa menyusun skripsi di jurusan keperawatan program angkatan 2007 Fakultas Kedokteran Universitas Brawijaya. Skripsi. Malang: UniversitasBrawijaya

Pihasniwati. (2008). Psikologi konseling. Yogyakarta: Bidang Akademik UIN Sunan Kalijaga Yogyakarta

Purnamaningsih, E.H. (1998). Efektivitas terapi perilaku kognitif untuk mengurangi kecemasan berbicara di muka umum. Jurnal Psikologi Universitas Gadjah Mada. (1), 6567

Scheier, M.F. (1993). On the power of positive thinking: The Benefits of Being Optimistic. Sage Publications, 2 (1): 26-30.

Schultz, D. (1991). Psikologi pertumbuhan. Yogyakarta: Penerbit Kanisius.

Seniati, L. (2011). Psikologi eksperimen. Jakarta: Indeks

Stolz, Paul G. (2005). Adversity quotient: mengubah hambatan menjadi peluang. Jakarta: Penerbit Gramedia. 
Seligman, M. (2008). Menginstal optimisme. Bandung: Momentum

Suseno, M.N. (2011). Modul Praktikum Statistika. Yogyakarta: Laboratorium Psikologi Fakultas soshum UIN Sunan Kalijaga

Susetyo, F. (1999). Hubungan berpikir positif dan jenis kelamin dengan kecenderungan agresi reaktif remaja. Psikologika, (7), 51-62

Tim Penyusun Kamus Besar Bahasa Indonesia. (1990). Kamus Bahasa Indonesia. Jakarta: Bumi Aksara.
Tresna, I. Gede. (2011). Efektivitas konseling behavioral dengan teknik desensitisasi sistematis untuk mereduksi kecemasan menghadapi ujian. Tesis. Bandung: Universitas Pendidikan Indonesia

Trismiati. (2004). Perbedaan tingkat kecemasan antara pria dan wanita akseptor kontrasepsi mantap di RSUP dr. Sardjito Yogyakarta. Psyche, 1 (1), 1-15. 


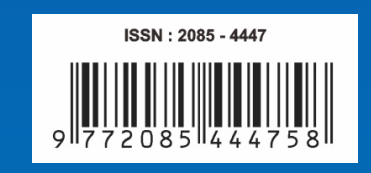

